\title{
5. Rethinking the role of the patent office from the perspective of responsive regulation Peter Drahos $^{1}$
}

\section{INTRODUCTION}

Patent offices, especially the world's largest patent offices, contribute to uncertainty. In 2011 almost 1 million patents were granted around the world, bringing the total number of patents in force to an estimated 7.88 million. $^{2}$ The hundreds of thousands of patents that are issued by patent offices every year produce a state of flux in the obligations of third parties in the marketplace. Each new patent generates exclusivity rights and corresponding obligations. Trade in these patents through assignment and licensing intensifies the flux. This flux generates uncertainty. The uncertainty has two basic sources. A company making product $\mathrm{X}$ cannot be sure that it has found all the patents relevant to product $\mathrm{X}$ in all the jurisdictions in which it is operating (completeness uncertainty) and, where it has found relevant patents, there are likely to be, at least for some patents, interpretive uncertainties - what does the patent cover and what does it not? Would the patent be upheld by a court? It is not only granted patents that are a source of uncertainty. Published patent applications also contribute (more than 2 million applications were filed worldwide in 2011). ${ }^{3}$

Uncertainty is no friend of property rights and efficiency. Mangling the poet Robert Frost's phrase one might say that 'good fences make good property rights'. Hayek describes law, liberty and property as being part of

1 My thanks go to Fred Abbott, John Braithwaite, Carlos Correa and Konstantinos Karachalios for their constructive suggestions.

2 World Intellectual Property Organization [WIPO], World Intellectual Property Indicators, Geneva, WIPO, 2012, p. 7.

3 WIPO, World Intellectual Property Indicators, Geneva, WIPO, 2012, p. 6. 
'an inseparable trinity'. ${ }^{4}$ The task of law, as he saw it, was to draw boundaries using rules so that people would not interfere in each other's freedom and so could transact with each other with high certainty. ${ }^{5}$ Hayek would probably be disappointed by the performance of today's patent system if he were to judge it by his goals of what law and property rights are meant to achieve.

Of course, there are efforts to deal with the uncertainty being generated by the world's patent systems. One only needs to spend a few minutes on the internet to realize there are many companies offering patent mapping or patent landscaping services. The World Intellectual Property Organization (WIPO) has started some patent mapping on important complex technologies such as vaccines for infectious diseases. ${ }^{6}$ Where patent mapping reports are publicly available, they do reveal in detail the large scale of patenting going on. WIPO's report on vaccines revealed a group of almost 12,000 patent families (amounting to over 51,000 patents/published applications), with most of that activity taking place after the $1980 \mathrm{~s}$, in line with the general trend of increasing patent applications in the 1980s and

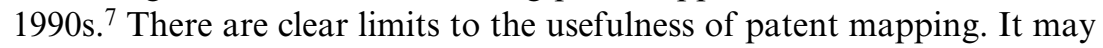
not resolve completeness uncertainty for a firm because patent applications may not contain vital information, thereby increasing their chances of not being found. One study of pharmaceutical patents in five developing countries found that a great proportion of pharmaceutical patents do not include the known generic name of the drug to which the patent relates in the title, abstract or claims. ${ }^{8}$ Patent mapping also increases interpretive uncertainty (more patents to interpret). It also requires one to be able to manage complexity, meaning that one has to manage many component parts of a system. ${ }^{9}$ In the US interesting business models have emerged in

4 F.A. Hayek, Law, Legislation and Liberty, London and New York, Routledge Classics, 2013, p. 102.

5 F.A. Hayek, Law, Legislation and Liberty, London and New York, Routledge Classics, 2013, p. 103.

6 WIPO, 'Patent Landscape Report on Vaccines for Selected Infectious Diseases', Geneva, WIPO, 2012, p.20, http://www.wipo.int/export/sites/www/ freepublications/en/patents/ (accessed 4 March 2013).

7 WIPO, 'Patent Landscape Report on Vaccines for Selected Infectious Diseases', Geneva, WIPO, 2012, p. 20, http://www.wipo.int/export/sites/www/ freepublications/en/patents/ (accessed 4 March 2013).

8 See C. Correa, 'Pharmaceutical Innovation, Incremental Patenting and Compulsory Licensing', Research Paper No. 41, South Centre, Geneva, 2011, http://www.southcentre.org/index.php?option $=$ com_content\&view $=$ article\&id= 1601\%3Ap (accessed 8 April 2013).

9 I use the term complexity here to refer to systems in which there are many 
response to patent uncertainty. The company RPX, for example, acquires patents from a variety of sources and then uses this portfolio to offer a protection service to its clients in exchange for an annual fee. In RPX's words, clients receive 'a license to every patent and patent right we own. We will never assert or litigate the patents in our portfolio'. ${ }^{10}$ Companies like RPX exist because other companies developing products in complex technology fields such as information technology face patent landscapes involving thousands or tens of thousands of patents. A company like Apple or Google might see an advantage in paying for RPX's services because it removes some patents from circulation that might otherwise affect its product development strategies.

In this short chapter I want to focus on the part played by patent offices in the production of uncertainty and complexity. Clearly they play a crucial part since their decisions about patent applications determine the supply of patents to the market. More specifically, I want to ask and sketch answers to two questions. What ideal should guide a patent office when it comes to its regulatory duties? Is there a regulatory approach that can help implement this ideal?

\section{THE PATENT SOCIAL CONTRACT}

Elsewhere I have argued that the ideal that should guide patent offices is the patent social contract. ${ }^{11}$ I do not want to repeat those arguments here, but for the purposes of answering my two questions I need to make the following points. The version of the patent social contract that I defend is the social value conception rather than the disclosure version. The patent applicant must deliver something of potential social value to society in exchange for which the applicant is entitled to a patent. Disclosure is not the essence of the bargain, innovation is. The not-so radical idea behind the patent social contract is that patents are meant to help society achieve higher levels of technological innovation than it otherwise would in the

known parts. This is a simple view of complexity and not to be confused with the application of complexity theory to social systems and institutions. For a discussion of the latter see J. McGlade and E. Garnsey, 'The Nature of Complexity', in McGlade, J., and Garnsey, E. (eds.), Complexity and Co-Evolution: Continuity and Change in Socio-Economic Systems, Cheltenham, UK and Northampton, MA, USA, Edward Elgar, 2006, p. 1.

10 See http://www.rpxcorp.com/ (accessed 4 March 2013).

11 P. Drahos, The Global Governance of Knowledge: Patent Offices and their Clients, Cambridge, Cambridge University Press, 2010. 
absence of patents. We desire technological innovation because most of us believe it contributes to progress (I emphasize technological since there is considerable scepticism at present concerning the contribution of financial innovation to progress). Through the patent institution society is, as it were, contracting for a better future. That at any rate is the theory. As Chapter 4 in this volume by Haiyang Zhang shows, some economists are sceptical about whether in fact patent systems have lived up to this promise. Moreover, even if we have some evidence that a patent system has benefitted one or two countries it does not follow that it will benefit the more than 190 other countries in the world.

One of the chief virtues of focussing on the patent social contract is that it brings the role of a patent office into sharp focus. Under the contract, society deputizes the patent office to act on its behalf to ensure that the inventor upholds its end of the bargain and delivers something that is genuinely new in exchange for the grant of the monopoly. The patent office is society's agent and its primary obligations are towards society. Of course, these days most offices are funded out of the fees that they collect from patent applicants. But it does not follow from this that the terms of the patent social contract or the duties of the patent office under it are affected by the adoption of the user-pays principle. Pharmaceutical companies, for example, pay large fees to drug registration authorities when they submit medicines for marketing registration. But no-one can seriously argue that this in some way changes the obligations of a drug registration authority as an independent regulator when it comes to evaluating medicines for toxicity and efficacy. A widespread assumption of the regulation literature is that we achieve better regulatory outcomes when we have independent central banks, independent competition authorities, independent financial regulators and so on. In short, independence should be a primary virtue of regulators. Regulatory capture is generally seen as a bad thing.

We should also be clear that the patent office is a regulatory agency with regulatory powers. This is perhaps a description that is not applied often enough to patent offices. If we take as our starting point, as economists often do, the free market and ask whether it will optimally allocate resources to invention then, at least on some economic views, the answer is no. ${ }^{12}$ Since invention information can usually be copied at less cost than its original costs of production, it follows it is better to be a copier than an originator. Under this logic everyone waits for everyone else to choose the role of originator, with the result that no-one so chooses. The patent

12 For a discussion of this market failure view of the free market in the case of innovation see Chapter 4 by Haiyang Zhang in this volume. 
system is a form of regulatory intervention designed to correct for this failure of the market. It is not the only form of regulatory intervention and moreover for some types of information discovery processes, such as those in basic science, the patent system has very little chance of working. ${ }^{13}$

Summing up, we can say that the patent office is chartered under the patent social contract to regulate markets in innovation, the overall regulatory goal being to increase innovation. As Carsten Fink points out in Chapter 2 in this volume and as is widely accepted, there is no simple linear relationship between intellectual property statistics and innovation. If a patent office has issued at the end of one year double the number of patents to residents compared to the previous year it does not mean that the country has become twice as innovative. The explanation for the doubling of the number of patents may be as prosaic as a change in the number of allowable claims per patent application. In fact, operating under a social contract in which it is intervening in innovation markets, a patent office should be aware of the possibility that by doubling the number of patents it may well be hampering innovation and so failing in its regulatory duty in much the same way as when an environmental regulator fails when it issues too many forestry logging permits, thereby damaging the forests it is obliged to protect. The basic point, which is perhaps not made often enough, is that the patent office is a regulator of the free market for innovation.

At this point in the argument someone might object that even if the patent office is a regulator it does not have the duties of a regulator. The task of a patent office, it might be argued, is simply to issue patents to the marketplace. The uses to which those patents might be put are not the affair of a patent office. We can label this view of the role of a patent office as 'some care, no responsibility'. Perhaps this objection might be accepted if the goal of a society was simply to increase the number of patents. But if the goal of society is to use the patent system to obtain more innovation then the duty of the patent office as a regulator is to consider the effects of a decision to continue intervening in the marketplaces of innovation through the supply of more and more patents. This is a direct responsibility under the patent social contract that the patent office cannot say belongs to other regulators such as a competition regulator. One can

13 On the need for government to fund basic science see K. Arrow, 'Economic Welfare and the Allocation of Resources for Invention', in National Bureau of Economic Research, The Rate and Direction of Inventive Activity, NJ, Princeton University Press, 1962, p.609, at p.623. Prizes and contests have been much discussed by economists as a form of intervention. See S. Scotchmer, Innovation and Incentives, Cambridge, MA, The MIT Press, 2004, pp.41-53. 
draw a parallel here with the duty of a central bank regulator. Central banks have to make decisions about the supply of money, but they are not chartered for that purpose. Rather the goal of monetary policy has to do with the control of inflation and ultimately the financial stability and welfare of a country. Money supply is not a goal in itself but a means to a goal. No central bank would, for instance, continue to increase money supply irrespective of the impact on the market, unless it wanted to engineer a hyperinflation collapse of its economy. In a similar way, no patent office should say that its only task as a regulator is to issue more and more patents. Much like central banks, patent offices have to assess their market interventions with a great deal of care. Retreating into the splendid isolation of 'some care, no responsibility' is not an option for central banks and should not be one for patent offices.

The remainder of the chapter argues that responsive regulation offers a patent office some guidance as to how it might approach its regulatory task. My discussion is not intended to be exhaustive of the possibilities, but merely illustrative. Responsive regulation has been the most influential theory of the last two decades in regulatory scholarship and so it seems a worthwhile question to ask whether patent offices might gain something from it. ${ }^{14}$ What follows is an analysis of what patent offices ought to do under the ideal of responsive regulation. As Fred Abbott observed in his comments on this chapter, much of what I argue for is a virtual antithesis of current trends. I am not especially optimistic about the capacity of patent offices to think creatively about reversing these trends. My study of patent offices revealed that they do not really have a conception of themselves as regulators with duties to the public. Instead I found that the main users of the system, multinational enterprises, were seen by offices as being their real clients. Of course, the heads of patent offices would probably strenuously deny that society had become invisible to their respective offices, but my study was more akin to a street life study in which I interviewed examiners and middle managers who spoke about the realities of the daily grind of meeting targets and quotas, as well as having to deal with pressures from attorneys anxious to secure patents for their clients. These kinds of conditions are breeding grounds for capitulation and capture. ${ }^{15}$

14 The classic statement of the theory is I. Ayres and J. Braithwaite, Responsive Regulation: Transcending the Deregulation Debate, Oxford, Oxford University Press, 1992. For an account of the origins of the theory see J. Braithwaite, 'The Essence of Responsive Regulation', UBC Law Review, vol. 44, 2011, p. 475.

15 J. Braithwaite, Regulatory Capitalism: How It Works, Ideas for Making it Work Better, Cheltenham, Edward Elgar, 2008, p.134. 
This does raise the question of what might lead to the kind of responsive institutionalism for innovation that I develop in this chapter (depicted in Figure 5.1 at the end of this chapter). This is a question about regulatory change, indeed global regulatory change that is well beyond the scope of my present analysis. But if significant change is to come to the patent system it will most probably be generated by a perceived pattern of crisis that gains a significant level of public recognition. Crisis and anxious mass publics have been recurrently important factors in globalizing new regulatory models. Often the crisis has been a single event such as the Titanic, Chernobyl, Bhophal, the Torrey Canyon, or a financial crash, but a pattern of regulatory failure can also bring mass concern into play, as shown by the influence of Rachel Carson's Silent Spring and Ralph Nader's Unsafe at Any Speed. ${ }^{16}$ Over its history the patent system, which is meant to generate new knowledge as a public good, has been linked to some major public 'bads' - its adverse impact on free trade in the nineteenth century, its link to oligopoly market power that led to strong competition law responses beginning in the US and more recently its impact on innovation and various access problems, most notably access to medicines. ${ }^{17}$ Public concern has impacted on the patent regime in the context of access to medicines, but for the most part the public 'bads' to which the system has been linked remain a matter of technical discussion, analysis and debate. More will be needed to capture public interest than debates over how to best estimate the social returns from the patent system. For the time being the system will lurch on in the direction of incremental reform under the watchful eye of the powerful industrial groups that have colonized the policy reform process.

Before moving on to discuss responsive regulation in more detail, the next section offers some brief observations about the implications for emerging markets of analysing a patent office's decisions as a form of regulatory intervention.

16 J. Braithwaite and P. Drahos, Global Business Regulation, Cambridge, Cambridge University Press, 2000, p. 500.

17 The literature on these topics is vast. For overviews see H.V.J. Moir, Patent Policy and Innovation: Do Legal Rules Deliver Effective Economic Outcomes, Cheltenham, UK, Edward Elgar, 2013; G. Ghidini, Innovation, Competition and Consumer Welfare in Intellectual Property Law, Cheltenham, UK, Edward Elgar, 2010; M. Boldrin and D.K. Levine, Against Intellectual Property, Cambridge University Press, 2008; A.B. Jaffe and J. Lerner, Innovation and Its Discontents: How Our Broken Patent System Is Endangering Innovation and Progress and What To Do About It, Princeton University Press, 2004. 


\section{PATENT OFFICES IN EMERGING MARKETS}

Independent regulators are usually seen as producing better decisions than captured ones. If we look at the history of central banking, the evolution of independence of central banks from private and political control is one of the great achievements of twentieth century financial regulation. ${ }^{18}$ Central banks have their origins in private entities that eventually became independent public institutions. ${ }^{19}$ As mentioned above, my study of patent offices suggests that many developing country offices do not fit the mould of the independent regulator. Rather they are unduly influenced in their decision-making by a combination of the Trilateral Offices (the US Patent and Trademark Office, the European Patent Office and the Japanese Patent Office) and big business. An argument for the independence of a patent office should not be construed as an argument against cooperation. Cooperation amongst patent offices on matters such as data collection, information exchange and transparency of the patent system is important. The history of central banking is full of examples of the virtues of cooperation. ${ }^{20}$ But the central banking story does suggest that it has to be cooperation amongst regulators with some scope for autonomous decision-making. One priority for all developing country governments should be to assess the independence of their patent offices.

Another priority for emerging markets should be to avoid buying into trade agreements that formally constrain the independence of their respective patent offices. The Agreement on Trade-Related Aspects of Intellectual Property Rights 1994 (TRIPS) leaves a government with considerable scope to preserve the autonomy of its patent office and therefore to regulate patent supply to innovation markets. TRIPS does not define invention, set a level of inventive step to be followed, prescribe a standard of usefulness, require a patent office to eliminate proven patent-quality-improving procedures such as pre-grant opposition, interfere in procedural innovation by a patent office or require a patent office to follow the decisions of another office on patent applications. However, bilateral agreements, as well as the

18 On the importance of this to financial regulation see J. Braithwaite and P. Drahos, Global Business Regulation, Cambridge, Cambridge University Press, 2000, ch. 8 .

19 R.N. Cooper, 'Almost a Century of Central Bank Cooperation', BIS Working Paper, 198, 2006, p. 3, http://econpapers.repec.org/paper/bisbiswps/198. htm (accessed 8 April 2013).

20 For a discussion see R.N. Cooper, 'Almost a Century of Central Bank Cooperation', BIS Working Paper, 198, 2006, http://econpapers.repec.org/paper/ bisbiswps/198.htm (accessed 8 April 2013). 
work of the Trilateral Offices behind the scenes, are beginning to probe and constrain these areas of autonomous decision-making (see Chapter 15 by Mohammed El Said in this volume). Persistent global financial instability is seeing emerging markets begin to explore the logic of decoupling themselves from the effects of Western regulatory prescriptions for dealing with this instability. Part of this logic seems to be deepening cooperation amongst themselves (see Chapter 6 by Padmashree Gehl Sampath and Pedro Roffe this volume), as well as creating new institutions of cooperation such as the decision to establish a BRICS development bank. ${ }^{21}$ This same decoupling logic should be applied by developing countries to looking at the implications of trade agreements for the regulatory autonomy of their patent offices. Independent central banks have proven crucial to helping the major developing countries cope with financial crises that originated in the US and EU. Developing countries should also be doing what they can to guard (or in some cases recapture) the independence of their patent offices.

\section{RESPONSIVE REGULATION}

Responsiveness as an ideal in law goes back at least to the tradition of legal realism. ${ }^{22}$ The American Realists argued that legal institutions should be more responsive to both the diversity of social interests and the changing nature of those interests. The path to responsiveness was seen to lie in systems of legal decision-making that were more open to knowledge, and driven by purposes and outcomes rather than the formalistic reproduction of rules. A responsive law system 'perceives social pressures as sources of knowledge and opportunities for self-correction'. ${ }^{23}$ Responsive regulation adopts the ideal of responsiveness. Epistemologically it is committed to working towards a greater knowledge and understanding of the business cultures it seeks to regulate. ${ }^{24}$ Contextual understanding is crucial because the guiding idea of responsive regulation is that a regulator should assess

21 See 'BRICS Bank Will Complement Other Multilateral Lenders: P. Chidambaram', The Economic Times, 1 April 2013, http://articles.economic times.indiatimes.com/2013-04-01/news/38189713_1_brics-bank-asian-develop ment-bank-world-bank.

22 P. Nonet and P. Selznick, Law and Society in Transition: Toward Responsive Law, New York, Harper and Row, 1978, pp. 73-4.

23 P. Nonet and P. Selznick, Law and Society in Transition: Toward Responsive Law, New York, Harper and Row, 1978, p. 77.

24 J. Braithwaite, 'Responsive Regulation and Developing Economies', World Development, vol. 34, no. 5, 2006, p.884, at p. 885 . 
how well actors are regulating themselves before it intervenes. Responsive regulation, however, does not defer to self-regulation. Nor is it driven by a rule-punishment model (if $A$ breaches rule $X$ then punishment $Y$ ). Instead it focuses on a set of regulatory options that will maximize the chance of A complying with rule $\mathrm{X}$. These options such as self-regulation, deterrent penalties and punishment are well known, but what is distinctive about responsive regulation is its sequencing of these options in the form of a regulatory pyramid. ${ }^{25}$

The key idea behind the pyramid is that punishment and persuasion should be linked in a certain sequence that always begins with persuasion at the base of the pyramid and ends with the most punitive sanction at the apex of the pyramid. The assumption that lies behind this escalation sequence is that there are different actor types - rational, virtuous, irrational or incompetent. Dialogue will work with a virtuous actor, but not necessarily a rational actor that calculates compliance in cost-benefit terms. With such actors a regulator will have to resort to a level of deterrence that makes non-compliant behaviour too risky.

Located at the base of the pyramid are the tools of dialogue and persuasion (for example, guidelines, protocols and educational strategies). At this level of the pyramid actors are assumed to want to do the 'right thing'. As one moves up the pyramid, the tools of regulation begin to assume a more coercive character until, at the top of the pyramid, there is some form of incapacitation (this depends on the area of regulation but may involve imprisonment, suspension of trade, loss of licence and so on). Where the regulator is unsuccessful at the bottom of the pyramid, he or she can move up the pyramid to deploy more coercive tools. There is a presumption in favour of a regulator starting at the bottom of the pyramid with dialogic tools, even when dealing with serious breaches. ${ }^{26}$

A straightforward application of this classic enforcement pyramid model by a patent office would be to presumptively trust the information it received from a patent applicant, but then begin a process of escalation to other levels of the pyramid once it had suspicions that the applicant was gaming the system. One of the problems is that patent office procedures do allow applicants a lot of scope for manoeuvring. Still there is no reason why patent offices could not be much more active in using the various levels of an enforcement pyramid such as audits and the use of outside

25 J. Braithwaite, Restorative Justice and Responsive Regulation, Oxford, Oxford University Press, 2002, pp. 30-31.

26 J. Braithwaite, Restorative Justice and Responsive Regulation, Oxford, Oxford University Press, 2002, p. 30. 
experts as a check on this manoeuvring, even in cases where they were unsuccessful in obtaining procedural reform.

Responsive regulation is a theory that has over the last two decades been refined through analysis and debate by scholars and practitioners, as well as through its adoption by regulatory agencies. ${ }^{27}$ It has moved well beyond its origins in business regulation and enforcement to become a more generalized theory of regulation and governance that moves beyond the enforcement pyramid and compliance into deeper questions about how to achieve broader regulatory purpose, how regulatory learning takes place, and the links between institutional integrity and regulation. ${ }^{28}$ It has become a theory of responsive institutionalism. In the section that follows I want to draw in particular on the approach of networked pyramidal governance that has emerged from an integration of responsive regulation with theories of networked governance in order to sketch a model of responsive institutionalism for innovation. ${ }^{29}$

\section{THE PATENT OFFICE AS A RESPONSIVE REGULATOR}

Unlike many regulatory agencies, a patent office does not have responsibility for a specific industry (as do, for example, mining inspectorates,

\footnotetext{
27 For the history see J. Braithwaite, 'The Essence of Responsive Regulation', UBC Law Review, vol. 44, 2011, p. 475.

28 Examples of works that have moved it in this direction are J. Braithwaite, Restorative Justice and Responsive Regulation, Oxford, Oxford University Press, 2002; J. Braithwaite, Markets in Vice, Markets in Virtue, Australia, Federation Press, 2005; J. Braithwaite, T. Makkai and V. Braithwaite, Regulating Aged Care: Ritualism and the New Pyramid, Cheltenham, UK and Northampton, MA, USA, Edward Elgar, 2007; and V. Braithwaite, Defiance in Taxation and Governance: Resisting and Dismissing Authority in a Democracy, Cheltenham, UK and Northampton, MA, USA, Edward Elgar, 2009.

29 For this line of development see P. Drahos, 'Intellectual Property and Pharmaceutical Markets: A Nodal Governance Approach', Temple Law Review, vol. 77, 2004, p. 401; S. Burris, P. Drahos and C. Shearing, 'Nodal Governance', Australian Journal of Legal Philosophy, vol. 30, 2005, p.30; J. Braithwaite, 'Responsive Regulation and Developing Economies', World Development, vol. 34, no. 5, 2006, p. 884; P. Drahos, 'A Networked Responsive Regulatory Approach to Protecting Traditional Knowledge', in Gervais, D. (ed.), Intellectual Property, Trade and Development: Strategies to Optimize Economic Development in a TRIPS Plus Era, Oxford, Oxford University Press, 2007, p. 385; and J. Braithwaite, T. Makkai and V. Braithwaite, Regulating Aged Care: Ritualism and the New Pyramid, Cheltenham, UK and Northampton, MA, USA, Edward Elgar, 2007, pp. 315-17.
} 
food standards agencies or media regulators). Much like a tax regulator, a patent office deals with many industries. These days it is hard to think of an industry unaffected by patents simply because high technology techniques are applied to most areas of primary production whether it is mining or the growing of food. A patent office does not supervise or regularly inspect companies for compliance with particular standards in the way, for example, chemical companies are inspected for compliance with safety and environmental standards. Nor does the patent office investigate companies in the manner of a corporate and securities regulator. The principal regulatory function of a patent office is to make patent supply decisions about various innovation markets. Its role, as I suggested earlier, can be likened to that of a central bank making decisions about money supply. As a regulator of innovation markets, a patent office is not faced by a compliance problem, but rather by an information and intervention problem. It has to have information about the aggregated effects of its interventions in various markets. This task is dynamic and continuously complex.

Patent offices through the very nature of their operations generate a selection bias. Those who want patents for their inventions go to a patent office and those who do not want patents do not. It is easy to assume from the number of patent applications coming to the major patent offices that innovation depends on patents. Under the patent social contract, the patent office's obligation is to help society make innovation gains. Decisions not to grant patents are just as important in the quest for innovation gains as are decisions to grant patents. The first principle of responsive regulation for a patent office operating under the patent social contract properly construed is to be an active gatherer of information about innovation markets.

Under the ideal of responsiveness, the principle of information gathering entails developing a process of organizational learning about the effects of patents on communities or networks of innovation that do not use patents. A patent office gathering information solely from patentintensive networks of innovation simply compounds its problem of selection bias in learning about innovation. An example of where an innovation market can work without patents and did so for several decades before IBM led it into the patent era is the case of software. ${ }^{30}$ The free revealing of technological information is a practice that even owners of large patent portfolios engage in at various times. ${ }^{31}$ For example, Novartis, the Broad

30 P. Drahos with J. Braithwaite, Information Feudalism: Who Owns the Knowledge Economy?, London, Earthscan, 2002, p. 170.

31 For a discussion of free revealing in the innovation literature and its 
Institute and Lund University announced the completion of a genomewide map of genetic differences in humans and their relationship to type 2 diabetes in February of 2007 and made the results available to the global research community. ${ }^{32} \mathrm{~A}$ responsive patent office would look carefully at cases where its grant of patents might affect innovation networks operating on the basis of free or largely free revealing. There is an obvious efficiency argument for not adversely affecting free revealing - information once in existence can be distributed at zero or marginal cost.

How might a patent office implement the principle of information gathering? One critical point here is that patent offices need to break away from a consultation model in which critics of patents are given a ritualistic hearing and then it is back to business as usual for offices. ${ }^{33}$ Responsive regulation in this context means continuous engagement with and listening to those who can provide information about what is happening in innovation markets. This probably means establishing permanent working parties with a broad membership that well and truly moves beyond the usual suspects (patent attorneys, multinational patent owners and scientists or others who gain personally from patents) in certain crucial innovation markets such as biotechnology, clean energy technologies, nanotechnology, pharmaceuticals, software and so on. The Free Software movement is an example of a community that can provide patent offices with information about the effects of patents in the information technology market. Working parties on innovation markets would increase the information gathering capacity of an office and it would reduce the danger of regulatory capture, especially if standard protections against capture such as rotating memberships and public reporting are applied.

Establishing working groups in crucial innovation markets is one way in which a patent office can draw in networks to better manage the complex intervention problem that it faces. There are at least two other ways in which it can make use of networked governance to improve its performance as a responsive intervener. The first lies in forging networks of greater cooperation with other regulators and the second is to network pyramidal governance.

application to biotechnology see J. Hope, Biobazaar: the Open Source Revolution and Biotechnology, Cambridge, MA, Harvard University Press, 2008.

32 The data is available at http://www.broadinstitute.org/diabetes (accessed 4 March 2013).

33 On the dangers of participatory ritualism in regulation see J. Braithwaite, T. Makkai and V. Braithwaite, Regulating Aged Care: Ritualism and the New Pyramid, Cheltenham, UK and Northampton, MA, USA, Edward Elgar, 2007, ch. 7. 
For a patent office important information about the uses and abuses of patents might come from other regulatory authorities. A good example of why it is important for a patent office to establish cooperative network relationships with a wide range of regulators comes from the field of tax. The use of patents in tax strategies has become a major problem for states. ${ }^{34}$ For example, in the US the Republican Senator Chuck Grassley introduced a legislative provision to prevent corporations from 'reducing their tax bill by hundreds of millions of dollars each year by taking intellectual property of little to no value and donating it to a charity'. ${ }^{35}$ A much greater problem has been the use of intellectual property rights in transfer pricing games by multinationals. The sale or licensing of intellectual property rights is used to shift income from high tax jurisdictions to low tax jurisdictions. The scale of the problem has grown in magnitude. In the US, the Senate Permanent Subcommittee on Investigation, which has been examining the problem for several years, reported in detail on Microsoft's transfer of intellectual property assets to subsidiaries in Puerto Rico, Ireland and Singapore. ${ }^{36}$ The Puerto Rico transfer game saw US\$21 billion shifted for a saving of \$US4.5 billion in US taxes. ${ }^{37}$ In the Irish transfer pricing game Microsoft transferred intellectual property to a Microsoft entity in Dublin that in 2011 reported profits of $\$ 4.3$ billion on which it paid an effective tax rate of $7.3 \%$. This worked out to a profit of $\$ 11$ million per employee in this small Dublin office, a quite astonishing case of labour productivity. ${ }^{38}$

The issues are technical, but a basic problem for tax offices is that

34 Something that Drahos and Braithwaite warned about. See P. Drahos with J. Braithwaite, Information Feudalism: Who Owns the Knowledge Economy?, London, Earthscan, 2002, p. 88.

35 See American Jobs Creation Act of 2004, Public Law 108-357, 22 October 2004. Details are to be found at http://www.finance.senate.gov/newsroom/ranking/ release/?id=83f6b20e-3327-4619-8b92-36ce643ef5fe (accessed 3 March 2013).

36 The Microsoft case study is to be found in United States Senate Permanent Subcommittee on Investigations, 'Exhibit: Hearing on Offshore Profit Shifting and the U.S. Tax Code', 20 September 2012, pp. 19-23, http://www.hsgac.senate. gov/subcommittees/investigations/hearings/offshore-profit-shifting-and-the-ustax-code (accessed 3 March 2013).

37 United States Senate Permanent Subcommittee on Investigations, 'Exhibit: Hearing on Offshore Profit Shifting and the U.S. Tax Code', 20 September 2012, p.2, http://www.hsgac.senate.gov/subcommittees/investigations/hearings/ offshore-profit-shifting-and-the-us-tax-code (accessed 3 March 2013).

38 United States Senate Permanent Subcommittee on Investigations, 'Exhibit: Hearing on Offshore Profit Shifting and the U.S. Tax Code', 20 September 2012, p. 11, http://www.hsgac.senate.gov/subcommittees/investigations/hearings/ offshore-profit-shifting-and-the-us-tax-code (accessed 3 March 2013). 
applying the principle of arm's length pricing to cross-border licensing transactions by multinationals involving intellectual property rights in the core technologies of those multinationals (generally patents) is difficult because, unlike in the case of common goods and services, finding comparable prices for those transactions is much harder. ${ }^{39}$ Of course, the fact that these transactions involve many complex patents makes it difficult for tax offices to understand these arrangements in the first place. The networked governance version of responsive regulation recognizes that a regulator in managing systems complexity will need network partners that have information and capacities that the regulator does not have. Individual regulators are themselves part of complex systems (innovation systems, health systems, environmental systems etc.) about which they cannot have information omniscience. They confront a reality of nested complexity in which subnational, national, regional and global systems interact in a multitude of ways. For individual regulators the goal is to identify actors that have the best information about the particular problems that face the regulator. Staying with the example of patents and transfer pricing problems, it is clear that tax offices need patent offices as part of a tax office network aimed at disentangling transfer pricing arrangements. Some tax offices such as the Danish and UK offices have realized this and have begun to develop closer links with their respective patent offices. ${ }^{40}$

Tax offices clearly need patent offices, but equally patent offices need tax offices. As a responsive intervener in innovation, a patent office should be concerned to ensure that its supply of patents to innovation markets stimulates innovation and not tax strategizing. Information from a tax office about the uses to which individual multinationals are putting granted patents becomes a reason for a patent office to target the quality of its work not just in that sector, but with respect to particular multinationals. If, for example, patents are too easy to obtain, allowing a multinational to patent every minor step, then this simply increases the options for a multinational to use patents to move its income to offshore

39 For a discussion of the technical issues see Written Testimony of William J. Jilkins, IRS Chief Counsel, accompanied by Michael Danilack IRS Deputy Commissioner (International) of the Large Business \& International Division before the Senate Committee on Homeland Security and Governmental Affairs, Permanent Subcommittee on Investigations, Hearing on the Shifting of Profits Offshore by U.S. Multinational Corporations, 20 September 2012, http://www. hsgac.senate.gov/subcommittees/investigations/hearings/offshore-profit-shiftingand-the-us-tax-code (accessed 3 March 2013).

40 OECD, Dealing Effectively with the Challenges of Transfer Pricing, Paris, OECD Publishing, 2012, p.23, http://dx.doi.org/10.1787/9789264169463-en (accessed 3 March 2013). 
jurisdictions of tax convenience. In fact it would seem that patent offices have done more than their fair share over the last decade to assist multinationals (their most regular clients) in transfer pricing strategies. A study by JP Morgan reported the following:

Many multinationals appear to be centralizing many of their valuable IP [intellectual property] assets in low-tax jurisdictions. The reality is that IP rights are easily transferred from jurisdiction to jurisdiction, and they are often inherently difficult to value. ${ }^{41}$

One might have added to the last sentence the words 'but easy to get'. It is not only multinationals in the information technology business that take advantage of patent-enabled transfer pricing games. Patent licensing strategies that allow companies to wash licences through low tax jurisdictions are invaluable to multinational pharmaceutical companies that would simultaneously like to present governments with high prices for pharmaceutical products but low profits for tax purposes. ${ }^{42}$ Patents have become an integral part of a win-win game for pharmaceutical companies in which they obtain high product prices from governments but pay low taxes.

So far I have been suggesting that a responsive patent office should utilize network governance in various ways to increase its information about an innovation system before intervening in it with patent supply decisions. Although a patent office does not enforce the patents it issues, as an intervener in complex systems it can structure its decisions about intervention following the sequencing principles of pyramidal governance. Where, for example, it received information from a tax office about the persistent use of patents in transfer pricing strategies, it could target those companies and patent attorney firms responsible for using patents in this way for special attention. At the bottom of the pyramid, the first step would be warnings to these companies and their attorneys that their applications would now come in for special scrutiny. Special examinations teams could be formed to target applications from these companies. There is no reason why a patent office could not bring in outside experts to help in assessing these applications to make sure they really did meet the criteria of patentability. The concentrated use of resources in the form

41 JP Morgan, 'Global Tax Rate Makers' (2012), cited in United States Senate Permanent Subcommittee on Investigations, 'Exhibit: Hearing on Offshore Profit Shifting and the U.S. Tax Code', 20 September 2012, p.9, http://www.hsgac. senate.gov/subcommittees/investigations/hearings/offshore-profit-shifting-andthe-us-tax-code (accessed 3 March 2013).

42 This was pointed out to me by John Braithwaite. 
of special teams to focus on crucial sectors is a strategy that has paid dividends for tax offices and could be used to much greater effect by patent offices. ${ }^{43}$ The end game here for a patent office is to be pitching its smart networks against the smart networks of the multinationals that are using the system. Patent offices that rely on individual busy examiners rushing to meet quotas to make the call on patent applications will be intervening in innovation in ways that are deeply sub-optimal.

Ultimately, however, the pyramidal escalation by a patent office will not serve to improve the regulation of innovation unless a patent office is using the standards of patentability to target innovation as opposed to standards that lock in the roll out of more and more patents. A patent office in making patent supply decisions is engaged in standards-based regulation. The European Patent Office, for example, has to decide the inventive step requirement by reference to what is or is not 'obvious to a person skilled in the art'. ${ }^{44}$ There are many examples of patent statutes conferring regulatory discretion through standards whether it is where to draw the line between discovery and invention, the application of the morality criterion, what it is to industrially apply an invention, whether a patent application has been sufficiently disclosed and so on. A patent office can only carry out its tasks as a regulator under the patent social contract using standards. It seems unlikely, for example, that a legislature can issue drafting instructions for rules codifying what is obvious to a skilled chemist that would have much relevance in a decade or two. When a regulator has to intervene on society's behalf in a complex system such as innovation, then standards linked to a clear view of societal purpose are the only feasible form of guidance for a regulator.

As Geertrui Van Overwalle argues in Chapter 16 in this book, patent offices have to 'revitalize' their 'vertical regulatory function'. If we go back to the core idea of responsiveness in law, it is about learning from social pressures and this by implication requires open organizational forms capable of detecting, analysing and responding to those pressures. Responsive intervention into a complex system requires a regulator to have open systems of information gathering, to be engaged in a creative process of finding ways to connect with the social pressures that form the basis of learning and opportunities for self-correction. The ideal of responsiveness requires a patent office, as a first step, to come to some genuine

43 For a description of how tax offices have re-organized themselves to meet the challenges of transfer pricing see OECD, Dealing Effectively with the Challenges of Transfer Pricing, Paris, OECD Publishing, 2012, ch. 7, http://dx.doi. org/10.1787/9789264169463-en (accessed 3 March 2013).

44 See Article 56 of the European Patent Convention. 
understanding of innovation markets and networks of innovation. But the selection bias I mentioned earlier impoverishes the knowledge base of patent offices about innovation. One approach that I covered previously is for an office to constitute permanent working groups on innovation populated not by those few who gain from patents but by those capable of genuine reflective debate about the state of innovation in their particular technological area. These groups could help a patent office align standards of patentability, the inventive step standard in particular, with what technological communities in various sectors understand to be genuine innovation. This, of course, remains a pipe-dream. The major offices spend the bulk of their time servicing the needs of their multinational clientele, discussing ways in which to reduce the backlog of patent applications and speed up the granting of more and more patents. So, for example, they dream up fast-tracking initiatives for 'green' patent applications, not asking whether in fact their decision to increase patent supply to markets such as those in renewable energy will actually speed up innovation or diffusion of innovation in those markets. ${ }^{45}$ Their assumption is always that more patents equal more innovation.

Pyramidal regulation has used theories of networked and nodal governance to articulate a partnership principle of regulation. ${ }^{46}$ In deploying an enforcement pyramid, a regulator should look to network with partners who have information and capacities that the regulator does not. This part of responsive regulation was developed to answer the criticism that regulators, especially in developing countries, face capacity deficits of various kinds. ${ }^{47}$ For example, a tax regulator in a developing country may not have the capacity to identify sophisticated tax evasion schemes, but it can help overcome that deficit by enrolling the aid of a large accounting firm like a KPMG or a Deloitte. As it happens, even well-resourced tax regulators have recognized how important external partners are to improving their regulatory capacity. ${ }^{48}$

45 For a discussion of these initiatives see A. Dechezleprêtre, Fast-tracking Green Patent Applications: An Empirical Analysis, Geneva, Switzerland, ICTSD Programme on Innovation, Technology and Intellectual Property; Issue Paper No. 37; International Centre for Trade and Sustainable Development, 2013, http:// ictsd.org (accessed 3 March 2013).

46 J. Braithwaite, 'The Essence of Responsive Regulation', UBC Law Review, vol. 44, 2011, p. 475 at p. 476.

47 J. Braithwaite, 'Responsive Regulation and Developing Economies', World Development, vol. 34, no. 5, 2006, p. 884 at pp. 889-94.

48 OECD, Dealing Effectively with the Challenges of Transfer Pricing, Paris, OECD Publishing, 2012, ch. 7, http://dx.doi.org/10.1787/9789264169463-en (accessed 3 March 2013). 
Networked pyramidal regulation recognizes the truth that regulatory capacity is not just a capacity of state agencies but is widely scattered amongst business and civil society actors of all kinds. It also builds on the insight of the early work on the tightly woven social networks that render apparently large worlds small - only a small number of steps are required to enrol strength to compensate for weakness. ${ }^{49}$

Patent offices have experimented with the partnership principle of regulation, a good example being the Peer to Patent pilot program begun by the USPTO in 2007.50 Other patent offices such as the Australian, Japanese and UK offices also developed similar pilots. ${ }^{51}$ The basic idea was that volunteer experts would have the opportunity to review patent applications placed on a website, posting any prior art they thought that a patent examiner should take into account in assessing the application. Responsive regulation would see this as first steps in the right direction. The idea of citizen experts being engaged in an assessment of innovation is in keeping with the separation of powers principle that underpins much of the deeper normative dimensions of responsive regulation and turns it into a theory of responsive institutionalism. The key, however, is whether patent offices will embrace the transformative potential of a model like peer to patent and this, as I have argued, depends on how they construe their duty under the patent social contract. A good start would be to rename these programs Peer to Innovation.

A responsive patent office would under the partnership principle look to engage with partners who could help it not to interfere in innovation initiatives that were flourishing without patents. For example, if an organization like the International Maize and Wheat Improvement Center (more generally referred to under its Spanish acronym, CIMMYT ${ }^{52}$ ) launches an open access initiative for bio-assets that it holds because it takes the view that this will speed up the innovation cycle, then a responsive patent office would look to make CIMMYT a network partner. ${ }^{53}$ The goal of the partnership would be to make sure that any patents issued by the patent

49 The classic study is J. Travers and S. Milgram, 'An Experimental Study of the Small World Problem', Sociometry, vol. 32, no. 4, 1969, p. 425.

50 See http://www.uspto.gov/patents/init_events/peerpriorartpilotindex.jsp (accessed 4 March 2013). A second one-year pilot was started in 2010. There appear to be no further pilots planned.

51 Details of these can be found at http://www.peertopatent.org.au/main/ aboutp2p (accessed 4 March 2013), http://www.iip.or.jp/e/e_p2pj/ (accessed 3 March 2013) and http://www.ipo.gov.uk/peertopatent.htm (accessed 4 March 2013).

52 Centro Internacional de Mejoramiento de Maíz y Trigo.

53 The initiative is called 'Seeds of Discovery'. See http://seedsofdiscovery.org/ seed/how-we-work/sharing-bio-assets-and-benefits/. 
office complemented the goals of the open access project - minimizing the possibility of IP claims in order to maximize the freedom to breed in the case of CIMMYT.

Projects like CIMMYT's Seeds of Discovery are public goods that ultimately depend on acts of trust for their successful constitution. If the scientists who contribute to these open access initiatives see others being able to capture private benefits from their contributions with relatively little effort because patent offices are making it easy to obtain patents, then it is a safe prediction that those scientists will stop contributing to those public initiatives. Open access databases are public goods that depend profoundly on social assets such as trust and volunteerism. Individuals have to volunteer their time to make contributions to the databases, others have to check those contributions for quality and yet others have to review the operation of the database if it is to become a genuinely useful public good. A patent office that presides over an irresponsible proliferation of patents that disrupts the social assets on which public good initiatives depend robs the society it is meant to serve.

A responsive patent office would find no shortage of network partners to help it understand the dynamics of innovation and the role of open access principles in those dynamics. The concerns about the impact of patents on science and innovation have been there for some time. ${ }^{54} \mathrm{But}$ some scientists have started to take practical steps to try and connect the patent system to the goal of innovation. One such initiative led by the molecular biologist Richard Jefferson focuses on the design of algorithms that will bring a global and freely available public transparency to the patent system instead of the pay-per-window transparency that feeds the patent information industry. ${ }^{55}$

\section{CONCLUSION}

The real world costs of the patent system continue to mount. Some economists have come to the conclusion it is time to do away with the system, but real world politics will keep this idea confined to scholarly corridors for a

54 See The Royal Society, Keeping Science Open: The Effects of Intellectual Property Policy on the Conduct of Science, London, 2003 and more recently The Royal Society, Science as an Open Enterprise, London, 2012, http://royalsociety. org/policy/projects/ (accessed 3 March 2013).

55 Described as the 'Lens' (formerly the 'Patent Lens') it is an 'open resource to serve innovation cartography'. At the moment it covers some 90 jurisdictions. See http://lens.org/lens/ (accessed 4 March 2013). 


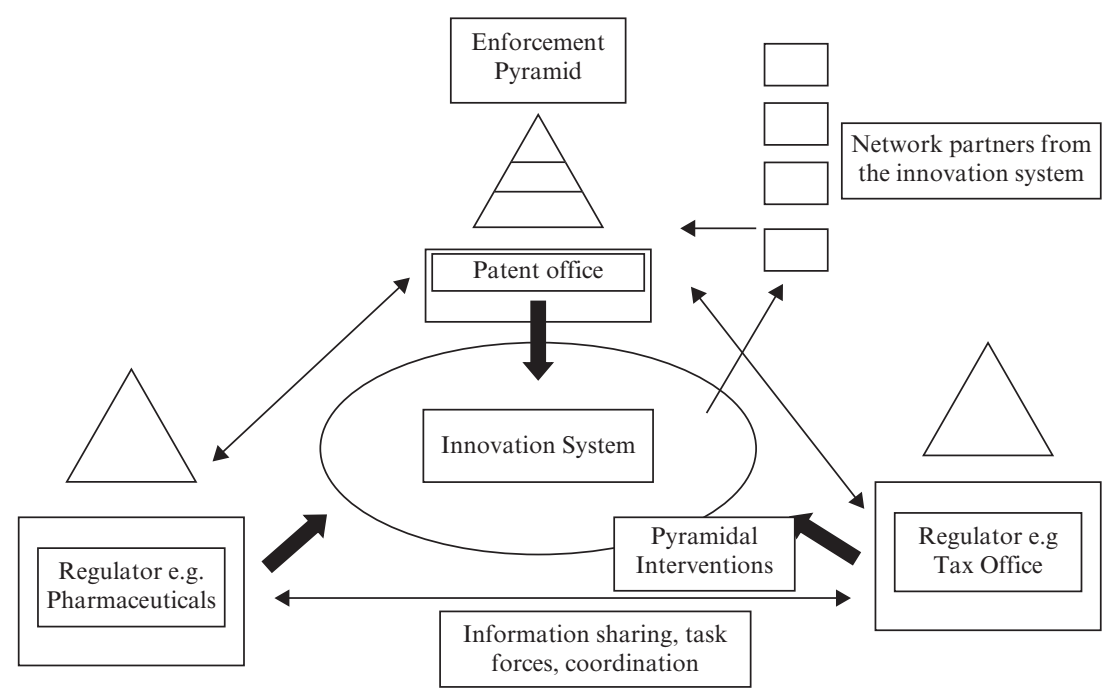

Figure 5.1 A model of responsive institutionalism for innovation

while longer. ${ }^{56}$ The need for patent reform is on most people's lips, unless it happens to be a reform that affects their ability to use the system to extract monopoly rents. So everyone mouths reform proposals while continuing to use the system to play beggar-thy-neighbour games. The use of patents in transfer pricing strategies has made some in the US realize that even it sometimes ends up as a victim in these games. Patent offices go along with all this because they have convinced themselves and their political masters that more patents really do equal more innovation. And in any case patent size gives states full of techno-nationalist ambition something to measure.

It could be different. Patent offices could see themselves as custodians of a society's most precious resource - the creative and innovative potential of its people. On any rational construction of the patent social contract, that is their duty. Like central banks they could see themselves as responsible interveners in complex systems. They could use the power of small worlds to construct networks with regulators and other partners to learn about the problems of oversupplying markets with patents. The same small worlds would allow them to enrol non-state partners which had capacities they did not to help them with pyramidal intervention. Figure 5.1 is a

56 M. Boldrin and D.K. Levine, 'The Case Against Patents', Working Paper 2012-035A, http://research.stlouisfed.org/wp/2012/2012-035.pdf (accessed 3 March 2013). 
simple sketch of the kinds of networks that would produce a responsive institutionalism for innovation. Each regulator, in deciding on an intervention in the system or a deployment of its enforcement pyramid, would draw on the information and capacities in the network. In keeping with the separation of powers principle, rather than having the power of command over the system, the regulator would have the opportunity to cause the power of the network to coalesce into peaks of information synthesis and intervention. The same network could be used to check abuses of the patent system. A tax office, a patent office, a pharmaceutical prices regulator, a securities regulator, a competition regulator and so on could form a task force to go after those companies that were committing the worst offences. Each regulator could move against a target company deploying the pyramidal powers it had in a cascading strategy of networked enforcement. The aim would be to bring the company to the negotiating table to sign a corporate integrity agreement, an enforceable undertaking or whatever other instruments a jurisdiction had as part of its enforcement options. Patent offices could help to build this responsive institutionalism for innovation, but they won't; at least not any time soon. 